\title{
Clinical utility of erlotinib for the treatment of non-small-cell lung cancer in Japanese patients: current evidence
}

This article was published in the following Dove Press journal:

Drug Design, Development and Therapy

31 July 2014

Number of times this article has been viewed

\author{
Yosuke Togashi' \\ Hidetoshi Hayashi ${ }^{1-3}$ \\ Kazuhiko Nakagawa ${ }^{2}$ \\ Kazuto Nishio' \\ 'Department of Genome Biology, \\ ${ }^{2}$ Department of Medical Oncology, \\ Kindai University Faculty of Medicine, \\ ${ }^{3}$ Department of Medical Oncology, \\ Kishiwada Municipal Hospital, \\ Osaka, Japan
}

\begin{abstract}
Gefitinib, an epidermal growth factor tyrosine kinase inhibitor (EGFR-TKI), has been approved in Japan for the treatment of patients with advanced non-small-cell lung cancer (NSCLC) based on Phase II clinical trials since 2002. Erlotinib, another EGFR-TKI, was also approved a few years thereafter. In 2004, activating mutations in the EGFR gene were discovered to be a predictive biomarker for EGFR-TKI treatment, and gefitinib, which is not effective for patients with EGFR wild-type NSCLC, has since been used only in patients with $E G F R$-mutated NSCLC. In contrast, erlotinib is potentially effective for the treatment of $E G F R$ wild-type NSCLC. Similar to gefitinib, erlotinib is also effective for EGFR-mutated NSCLC and has been used as an initial treatment for patients with advanced EGFR-mutated NSCLC. Both gefitinib and erlotinib can be used in a Japanese clinical setting. The approved daily dose of erlotinib $(150 \mathrm{mg})$ is equal to the maximum tolerated dose of erlotinib. In contrast, the daily dose of gefitinib has been set at $250 \mathrm{mg}$, which is approximately one-third of the maximum tolerated dose of gefitinib. Accordingly, a higher serum concentration can be achieved using erlotinib, compared with gefitinib. This advantage can be applied to the treatment of central nervous system metastases (brain metastasis and carcinomatous meningitis), the treatment of which is complicated by the difficulty drugs have penetrating the blood-brain barrier. Although patients with EGFR-mutated NSCLC respond dramatically to EGFR-TKIs, some patients have a poor response and the majority eventually undergo disease progression. To overcome such resistance, several novel treatment strategies, such as combination therapy and next-generation EGFR-TKIs, have been attempted.
\end{abstract}

Keywords: non-small-cell lung cancer, epidermal growth factor receptor tyrosine kinase inhibitor, erlotinib, EGFR mutation

\section{Introduction}

Lung cancer is the leading cause of cancer-related death in the developed world. ${ }^{1}$ Non-small-cell lung cancer (NSCLC) accounts for approximately $80 \%$ of all lung cancers, and despite recent advances in therapy for advanced NSCLC, its prognosis remains very poor. ${ }^{2}$ For most individuals with advanced NSCLC, cytotoxic chemotherapy is the mainstay of treatment based on moderate improvement in survival. However, the outcome of chemotherapy in such patients has reached a plateau in terms of the response rate $(25 \%-35 \%)$ and overall survival (OS; $8-10$ months). ${ }^{3,4}$ Epidermal growth factor receptor (EGFR) is recognized as an important molecular target in cancer therapy. ${ }^{5}$ Phase II trials using the EGFR-tyrosine kinase inhibitor (EGFR-TKI) gefitinib (Iressa Dose Evaluation in Advanced Lung Cancer 1 and 2; IDEAL1 and 2) have shown favorable outcomes. ${ }^{6,7}$ In Japanese patients, especially, the response rate
Correspondence: Yosuke Togashi Department of Genome Biology, Kindai University Faculty of Medicine, 377-2 Ohno-higashi, Osaka-Sayama,

Osaka 589-85I I, Japan

$\mathrm{Tel}+8 \mathrm{I} 72366022 \mathrm{I}$

Fax +8I 723676369

Email ytogashi@med.kindai.ac.jp 
was approximately $30 \%$. Based on these results, the use of gefitinib was approved in Japan prior to its approval in other countries. A larger Phase III trial (Iressa Survival Evaluation in Lung Cancer; ISEL), however, showed no superiority of gefitinib to best supportive care (median OS 5.6 months for gefitinib versus 5.1 months for best supportive care, hazard ratio $[\mathrm{HR}] 0.89, P=0.087) .{ }^{8}$ In this trial, however, gefitinib seemed to result in an improvement in survival among never-smokers and Asians, as has been reported in previous Phase II trials. ${ }^{6-8}$ In addition, somatic-activating mutations of the $E G F R$ gene (EGFR mutations) were discovered to be oncogenic driver mutations in NSCLC in 2004, and patients with NSCLC harboring EGFR mutations generally responded to EGFR-TKIs. ${ }^{9-11}$ In the Iressa Pan-Asia Study (IPASS), however, patients with EGFR wild-type NSCLC rarely responded to gefitinib. ${ }^{12,13}$ Therefore, gefitinib is now used only for $E G F R$-mutated NSCLC. In contrast to gefitinib, erlotinib - another EGFR-TKI - was shown to be superior to best supportive care in a large Phase III trial (BR.21) (median progression-free survival [PFS] 2.2 months for erlotinib versus 1.8 months for a placebo, HR 0.61, $P=0.001$; median OS 6.7 months versus 4.7 months, HR $0.70, P=0.001){ }^{14}$ The results of several trials seemed to suggest that erlotinib was effective not only for EGFR-mutated NSCLC, but also for $E G F R$ wild-type NSCLC. Here, this review summarizes erlotinib treatment in the Japanese clinical setting, where both gefitinib and erlotinib can be used as EGFR-TKIs.

\section{Structure and EGFR inhibitory activity of erlotinib}

The discovery that 4-anilinoquinazolines exhibit EGFR inhibitory activity led to the development of EGFRTKIs. ${ }^{15}$ Nanomolar concentrations of the quinazoline erlotinib ([6,7-bis $\{2$-methoxy-ethoxy $\}$-quinazolin-4yl]-[3-ethylphenyl]) amine (Figure 1) inhibit the activity of purified EGFR-TK and EGFR autophosphorylation in intact tumor cells, with 50\% inhibitory concentration values of $2 \mathrm{nmol} / \mathrm{L}$ and $20 \mathrm{nmol} / \mathrm{L}$, respectively. ${ }^{16}$ Erlotinib is 1,000-fold more potent against EGFR-TK than most other human kinases, including c-Src and insulin receptor TK. ${ }^{16}$

\section{Erlotinib for EGFR-mutated NSCLC}

In 2004, three groups in the US reported the landmark findings that a subset of NSCLC patients harbor activating mutations of $E G F R^{9-11}$ and that tumors positive for such mutations are highly sensitive to EGFR-TKIs, such as gefitinib and erlotinib. Indeed, most NSCLC patients who

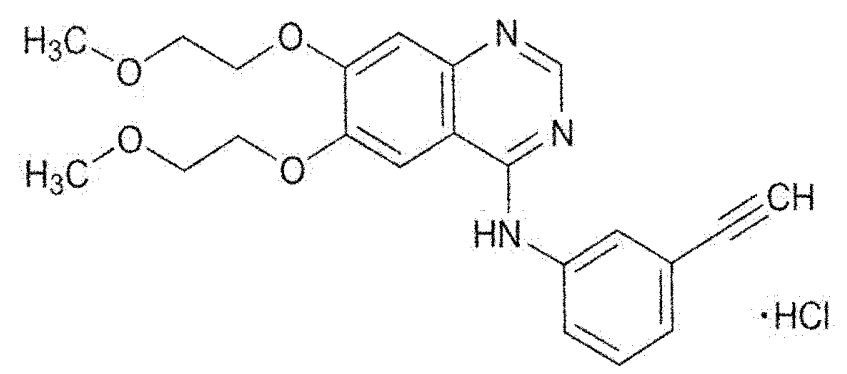

Figure I Structure of erlotinib. Erlotinib was developed based on 4-anilinoquinazolines.

experienced a marked response to EGFR-TKIs were found to harbor EGFR mutations. EGFR mutations are present predominantly among women, never-smokers, individuals with adenocarcinoma, and those of East Asian ethnicity. The prevalence of $E G F R$ mutations is approximately $20 \%-40 \%$ among East Asians and 10\% among Caucasians. ${ }^{17-22}$ The most common EGFR mutations in patients with NSCLC include short in-frame deletions in exon 19 and a specific point mutation in exon 21 at codon 858. Both mutations account for approximately $80 \%-90 \%$ of the EGFR mutations that were detected. Several studies have revealed that EGFR-TKIs are more effective against NSCLCs with an EGFR exon 19 deletion mutation compared with those with an exon 21 L858R mutation. ${ }^{23-25}$ Other less commonly detected sensitizing EGFR mutations include the $\mathrm{G} 719 \mathrm{~A} / \mathrm{C} / \mathrm{S}$ and $\mathrm{S} 720 \mathrm{~F}$ mutations in exon 18, the L861Q/R mutations in exon 21 , and the V765A, T783A, and S768I mutations in exon 20. In contrast, less commonly detected primary resistant $E G F R$ mutations include various insertion mutations in exon 20..$^{21,22,26}$

At first, EGFR-mutational analyses were performed using direct sequencing. However, the clinical specimens that are used to diagnose lung cancers (ie, sputum, pleural effusion, bronchial washing, and surgically resected tissue) contain numerous normal cells. Thus, a method capable of detecting EGFR mutations within a large background of wild-type $E G F R$ genes was required. Therefore, highly sensitive polymerase chain reaction (PCR) methods, such as PCR-Invader ${ }^{\circledR}$ (Hologic, Inc., Bedford, MA, USA), peptide nucleic acid-locked nucleic acid PCR clamp, Cycleave ${ }^{\circledR}$ PCR (Takara Bio Inc., Kyoto, Japan), and the Scorpion amplification refractory mutation system (Roche Diagnostics, Basel, Switzerland), have become widely used in the Japanese clinical setting. ${ }^{9,27-30}$ Both the sensitivities and the specificities of these assays are higher than $90 \%$, and formalin-fixed paraffin-embedded tissue, bronchofiberscopic brushing cytology, and pleural effusion cytology samples can be analyzed using these methods. ${ }^{31}$ In Japan, these highly sensitive methods have been widely introduced into clinical 
settings. Therefore, the Japanese treatment guidelines recommend that NSCLC, especially non-squamous cell lung cancer, be first analyzed for EGFR mutations before deciding upon an appropriate treatment.

In prior clinical trials of EGFR-TKIs, such as the ISEL and BR. 21 trials, the patients were not selected. ${ }^{8,14}$ Since the IPASS trial, ${ }^{13}$ however, patients participating in such clinical trials have been selected according to their EGFR mutation status. Therefore, the current evidence is based on such selected trials. Three large Phase III trials comparing erlotinib and cytotoxic platinum doublet standard chemotherapy as first-line treatments for patients with EGFR-mutated NSCLC (OPTIMAL, European Tarceva versus Chemotherapy [EURTAC], and ENSURE) revealed that erlotinib was superior as a first-line treatment in terms of PFS (Table 1). ${ }^{32-34}$ In addition, erlotinib was associated with an improved quality of life, compared with chemotherapy. ${ }^{35}$ In the OPTIMAL and EURTAC trials, however, no significant difference in overall survival was observed between the erlotinib group and the chemotherapy group because of the potential impact of crossover (Table 1). In Japan, Phase II trials examining first-line and second-line or third-line erlotinib treatment for EGFR-mutated NSCLC have demonstrated similar favorable results (Table 2). ${ }^{36,37}$ Based on these findings, erlotinib has been approved as a first-line treatment for EGFR-mutated NSCLC, and the Japanese treatment guidelines recommend gefitinib or erlotinib monotherapy for patients with EGFR-mutated NSCLC. A recent Japanese Phase III trial directly comparing gefitinib and erlotinib to demonstrate that noninferiority of gefitinib to erlotinib in terms of PFS resulted in a negative study, but no significant difference in PFS was seen between gefitinib and erlotinib for the treatment of patients with EGFR-mutated NSCLC (median PFS 8.9 months versus 10.1 months, $P=0.532$; median OS 32.0 months versus 26.6 months, $P=0.111$ ). A subset analysis revealed a prolongation of the PFS in the erlotinib arm, compared with the gefitinib arm, in patients aged $<65$ years (HR 1.357, $P=0.032) .{ }^{38}$ The detailed results of this study might help to decide which drug should be used.

\section{Erlotinib for EGFR wild-type NSCLC}

The BR.21 trial demonstrated that erlotinib is superior to best supportive care for the treatment of patients with $E G F R$ wild-type NSCLC, including squamous cell cancer, as analyzed using direct sequencing. ${ }^{14,39}$ Japanese Phase II trials have demonstrated that the use of erlotinib for pretreated patients with EGFR wild-type NSCLC seems to have a modest activity (Table 3). ${ }^{40,41}$ Among Caucasians, who are expected to have a lower frequency of EGFR mutations, no significant difference in the time to progression (median 3.0 months versus 3.9 months, $P=0.195$ ) or the OS (median 10.1 months versus 8.2 months, $P=0.986$ ) was observed between pemetrexed and erlotinib as a second-line or third-line treatment. ${ }^{42}$ Furthermore, among patients with squamous cell cancer, which rarely harbors EGFR mutations, those who received erlotinib had a significantly longer median time to progression (2.5 months versus 4.1 months, $P=0.006)$. A systematic review has shown a significant benefit of erlotinib in patients with EGFR wild-type NSCLC. ${ }^{43}$ However, a randomized trial comparing erlotinib and docetaxel as second-line treatments for EGFR wild-type NSCLC (TArceva Italian Lung Optimization tRial; TAILOR) has demonstrated that docetaxel is more effective than erlotinib (median PFS 2.9 months for docetaxel versus 2.4 months for erlotinib, HR $0.71, P=0.02$; median OS 8.2 months versus 5.4 months, HR $0.73, P=0.05) .{ }^{44}$ Similarly, a Japanese randomized Phase III trial of erlotinib versus docetaxel as a

Table I Phase III studies of erlotinib versus chemotherapy as a first-line treatment for patients with EGFR-mutated non-small-cell lung cancer

\begin{tabular}{|c|c|c|c|c|c|c|c|}
\hline Study & Country & $\begin{array}{l}\text { Treatment (number } \\
\text { of patients) }\end{array}$ & EGFR mutational analyses & ORR (\%) & $\begin{array}{l}\text { Median PFS } \\
\text { (months) }\end{array}$ & $\begin{array}{l}\text { Median OS } \\
\text { (months) }\end{array}$ & Reference \\
\hline \multirow[t]{2}{*}{ OPTIMAL } & People's & Erlotinib (82) versus & Exon 19 deletion or L858R & 83 versus 36 & I3.I versus 4.6 & 28.9 versus 22.7 & 22 \\
\hline & $\begin{array}{l}\text { Republic } \\
\text { of China }\end{array}$ & CBDCA plus GEM (72) & $\begin{array}{l}\text { PCR-based direct sequencing } \\
\text { performed at central laboratory }\end{array}$ & $P<0.000$ I & HR $0.16, P<0.000 I$ & HR I.04, $P=0.69$ & \\
\hline \multirow[t]{2}{*}{ EURTAC } & Europe & Erlotinib (86) versus & Exon 19 deletion or L858R & 58 versus 15 & 9.7 versus 5.2 & 19.3 versus 19.5 & 23 \\
\hline & & $\begin{array}{l}\text { CBDCA/CDDP plus } \\
\text { DOC/GEM (87) }\end{array}$ & $\begin{array}{l}\text { Sanger sequencing confirmed } \\
\text { using clamp or TaqMan assay }\end{array}$ & $P<0.000$ I & HR 0.34, $P<0.000 \mathrm{I}$ & HR I. .04, $P=0.87$ & \\
\hline \multirow[t]{2}{*}{ ENSURE } & People's & Erlotinib $(110)$ versus & Exon 19 deletion or L858R & 63 versus 34 & II .0 versus 5.5 & NA & 24 \\
\hline & $\begin{array}{l}\text { Republic } \\
\text { of China }\end{array}$ & CDDP plus GEM (I07) & & $P=0.000 \mathrm{I}$ & HR $0.33, P<0.000 I$ & & \\
\hline
\end{tabular}

Abbreviations: CBDCA, carboplatin; CDDP, cisplatin; DOC, docetaxel; EURTAC, European Tarceva versus Chemotherapy; GEM, gemcitabine; HR, hazard ratio; NA, not available; ORR, objective response rate; OS, overall survival; PCR, polymerase chain reaction; PFS, progression-free survival; EGFR, epidermal growth factor receptor. 
Table 2 Phase II studies of erlotinib for Japanese patients with EGFR-mutated non-small-cell lung cancer

\begin{tabular}{|c|c|c|c|c|c|c|}
\hline Study & $\begin{array}{l}\text { Number } \\
\text { of patients }\end{array}$ & $\begin{array}{l}\text { Treatment } \\
\text { line }\end{array}$ & EGFR mutational analyses & ORR (\%) & $\begin{array}{l}\text { Median PFS } \\
\text { (months) }\end{array}$ & Reference \\
\hline LOGiK0803 & 26 & $\begin{array}{l}\text { Second or } \\
\text { third line }\end{array}$ & $\begin{array}{l}\text { Exon } 19 \text { deletion or L858R } \\
\text { PCR-based direct sequencing, } \\
\text { invader assay, or clamp assay }\end{array}$ & 53.8 & 9.3 & 26 \\
\hline JO22903 & 102 & First line & $\begin{array}{l}\text { Exon } 19 \text { deletion or L858R } \\
\text { Scorpion ARMS }\end{array}$ & 78.4 & 11.8 & 27 \\
\hline
\end{tabular}

Abbreviations: ARMS, amplification refractory mutation system; ORR, objective response rate; PFS, progression-free survival; EGFR, epidermal growth factor receptor; PCR, polymerase chain reaction.

second- or third-line therapy (Docetaxel and Erlotinib Lung Cancer Trial; DELTA) demonstrated that erlotinib was inferior to docetaxel in an EGFR wild-type subpopulation (median PFS 1.3 months for erlotinib versus 2.9 months for docetaxel, HR 1.452, $P=0.010$ ) (Table 3). ${ }^{45}$ Therefore, Japanese clinicians do not use erlotinib prior to docetaxel in patients with EGFR wild-type NSCLC.

A Phase II trial examining erlotinib in Japanese patients with $E G F R$ wild-type NSCLC with a never or light smoking history resulted in a favorable response rate of $15.2 \%{ }^{46}$ EGFR mutations are predominant among never-smokers and individuals of East Asian ethnicity. ${ }^{17-22}$ Despite the use of highly sensitive methods to detect EGFR mutations, falsenegative results sometimes occur in patients with EGFRmutated NSCLC; therefore, such patients could be included in this study. In addition, a novel biomarker predicting the efficacy of erlotinib in patients with $E G F R$ wild-type NSCLC (ie, a ligand of EGFR; amphiregulin) may exist, and this procedure should be further performed. ${ }^{47-49}$

\section{Erlotinib for NSCLC unsuitable for chemotherapy}

A previous report has indicated that patients with EGFRmutated NSCLC and an extremely poor performance status might benefit from gefitinib. ${ }^{50}$ In contrast, a Phase III trial of erlotinib versus a placebo for patients with advanced NSCLC unsuitable for chemotherapy (TOPICAL) has demonstrated that the median OS period was similar between the two groups (3.7 months for erlotinib versus 3.6 months for the placebo, HR $0.94, P=0.46) .{ }^{51}$ In this trial, the study population was not selected for patients with EGFR-mutated NSCLC. Patients who develop a first-cycle rash might benefit from erlotinib, whereas those who do not develop a rash after 28 days are likely to have a shorter survival period. Although the number was very small $(\mathrm{n}=17)$, all the patients with $E G F R$ mutations who were assigned to the erlotinib arm developed a rash. If the patients had been selected as they would have been for gefitinib treatment, they might have benefited from the erlotinib treatment. In Japan, however, based on the results of a previous study and the Japanese treatment guidelines, clinicians usually use gefitinib for selected patients. ${ }^{50}$

\section{Maintenance therapy}

Maintenance therapy, which is defined as "any treatment that is given to keep cancer from progressing after it has been successfully controlled by the appropriate first-line therapy", has become an established paradigm for the treatment of patients with advanced NSCLC. ${ }^{52}$ The rationale for this strategy is that continuous treatment can delay disease progression and improve survival. Nowadays, various agents have been applied in maintenance regimens, such as bevacizumab, ${ }^{53}$ pemetrexed, ${ }^{54-56}$ and erlotinib ${ }^{57}$ for switching or continuous maintenance therapy. A Phase III study of erlotinib as a maintenance treatment in patients with non-progressive disease after first-line chemotherapy (Sequential Tarceva in Unresectable NSCLC; SATURN) has confirmed the

Table 3 Erlotinib for patients with EGFR wild-type non-small-cell lung cancer

\begin{tabular}{|c|c|c|c|c|c|c|c|c|}
\hline Study & Country & $\begin{array}{l}\text { Number } \\
\text { of patients }\end{array}$ & Treatment line & $\begin{array}{l}\text { EGFR mutational } \\
\text { analyses }\end{array}$ & $\begin{array}{l}\text { ORR } \\
(\%)\end{array}$ & $\begin{array}{l}\text { Median PFS } \\
\text { (months) }\end{array}$ & $\begin{array}{l}\text { Median OS } \\
\text { (months) }\end{array}$ & Reference \\
\hline BR.2I (Phase III) & Global & 115 & Second or third & Direct sequencing & 6.9 & NA & 7.9 & 12,29 \\
\hline Okayama (Phase II) & Japan & 30 & Second, third, or fourth & PCR clamp assay & 3.3 & 2.1 & 9.2 & 30 \\
\hline Hamamatsu (Phase II) & Japan & 20 & Third line & PCR clamp assay & 15 & 2.1 & 6.7 & 31 \\
\hline TAILOR (Phase III) & Italy & 112 & Second line & Direct sequencing & 3 & 2.4 & 5.4 & 34 \\
\hline DELTA (Phase III) & Japan & 109 & Second or third line & NA & 5.6 & 1.3 & 9.0 & 35 \\
\hline
\end{tabular}

Abbreviations: DELTA, Docetaxel and Erlotinib Lung Cancer Trial; NA, not available; ORR, objective response rate; OS, overall survival; PCR, polymerase chain reaction; PFS, progression-free survival; TAILOR, TArceva Italian Lung Optimization tRial; EGFR, epidermal growth factor receptor. 
efficacy and safety of erlotinib. ${ }^{57}$ The median PFS and OS were significantly longer with erlotinib treatment than with a placebo (median PFS 12.3 weeks versus 11.1 weeks, HR 0.71 , $P=0.0001$; median OS 12.0 versus 11.0 months, HR 0.81 , $P=0.0088)$. A biomarker analysis showed that patients with EGFR mutations exhibited a significantly greater PFS benefit from maintenance erlotinib (HR 0.10, $P=0.0001$ ) compared with those with $E G F R$ wild-type tumors (HR 0.780, $P=0.018$; treatment-by-mutation interaction $P=0.001)$. However, the $E G F R$ mutation status did not predict an OS benefit. In Japan, maintenance therapy with erlotinib is not recommended by the Japanese treatment guidelines and is not generally performed because many patients have EGFR mutations and careful clinical follow-up allows most patients to receive second-line or higher treatment.

\section{Combination regimens containing erlotinib}

Although patients with EGFR-mutated NSCLC dramatically respond to EGFR-TKIs and can have a long PFS, they cannot be cured.$^{58}$ Therefore, to achieve a longer survival period, combination regimens of chemotherapy and EGFR-TKIs have been tried. Even though previous Phase III studies in unselected populations have shown that the concurrent combination of chemotherapy and erlotinib did not improve survival compared with chemotherapy alone, ${ }^{59,60}$ sequential intercalated combination regimens of chemotherapy and erlotinib (First-line Asian Sequential Tarceva And Chemotherapy Trial; FASTACT) have been shown to enable a significant improvement in responses and PFS, especially in patients with adenocarcinoma. ${ }^{61}$ One explanation for this lack of efficacy with a concurrent combination is that $\mathrm{G} 1$ cell cycle arrest caused by EGFR-TKIs might reduce the cell cycle phasedependent activity of chemotherapy. In contrast, preclinical data showed that the sequential administration of EGFRTKIs after chemotherapy might be effective. ${ }^{62}$ To confirm this finding, FASTACT-2 was started in Asian countries. ${ }^{63}$ In this Phase III trial, patients with untreated advanced NSCLC were randomly assigned to receive six cycles of gemcitabine plus platinum with intercalated erlotinib (chemotherapy plus erlotinib; $150 \mathrm{mg}$ /day on days $15-28$, orally) or a placebo orally (chemotherapy plus placebo) every 4 weeks. All the patients in the placebo group were offered second-line erlotinib at the time of progression. The PFS was significantly prolonged with chemotherapy plus erlotinib versus chemotherapy plus placebo (median PFS 7.6 months versus 6.0 months, HR $0.57, P=0.0001)$. The median OS period for the patients in the chemotherapy plus erlotinib group and those in the chemotherapy plus placebo group was 18.3 months and 15.2 months, respectively (HR 0.79, $P=0.0420$ ). A statistically significant treatment benefit was observed in patients with EGFR mutations (median PFS 16.8 months versus 6.9 months, HR $0.25, P=0.0001$; median OS 31.4 months versus 20.6 months, HR 0.48, $P=0.0092$ ). However, no significant difference in either the median PFS or the OS was observed in patients with EGFR wild-type NSCLC in the chemotherapy plus erlotinib group versus those in the chemotherapy plus placebo group. In Japan, a Phase II trial of gefitinib and inserted cisplatin plus docetaxel in selected patients with EGFR mutations has revealed favorable outcomes (median PFS 19.5 months; median OS 48 months). ${ }^{64}$ At present, a large Phase III trial in selected patients with $E G F R$ mutations is being planned.

A Phase III trial of bevacizumab, an antiangiogenic agent, plus erlotinib versus erlotinib alone in advanced NSCLC after the failure of standard first-line chemotherapy (Bevacizumab/Tarceva [BeTa] trial) has shown that the addition of bevacizumab to erlotinib does not improve survival (median OS 9.3 months versus 9.2 months, HR 0.97 , $P=0.758$ ). Interestingly, the improvement of OS was more prominent among patients with $E G F R$-mutated NSCLC (HR 0.44) than among those with EGFR wild-type NSCLC (HR 1.11). ${ }^{65}$ In Japan, a similar randomized trial examining bevacizumab plus erlotinib as a first-line treatment in selected patients with $E G F R$ mutations has demonstrated favorable results (median PFS 16.0 months for bevacizumab versus 9.7 months for control, HR 0.54, $P=0.0015){ }^{66}$

\section{Beyond progression}

In view of the nature of EGFR-TKI-resistant tumors and disease flare after the withdrawal of EGFR-TKIs ${ }^{67}$ several strategies have been developed to overcome acquired resistance, including switching to cytotoxic therapies ${ }^{68}$ or irreversible EGFR-TKIs ${ }^{69}$ in combination with other signal inhibitors, ${ }^{70,71}$ local therapy, ${ }^{72,73}$ or cytotoxic therapies. ${ }^{74}$ Nevertheless, the best treatment mode remains unclear.

A few clinical trials investigating treatment strategies after EGFR-TKI failure are ongoing, including a Phase II Study of Continued Erlotinib Beyond Response Evaluation Criteria in Solid Tumors Progression in Asian Patients with EGFR Mutation-Positive NSCLC (ASPIRATION) and A Study of Iressa ${ }^{\circledR}$ Treatment Beyond Progression in Addition to Chemotherapy Versus Chemotherapy Alone (IMPRESS). More importantly, deeper molecular characterization of the primary 
Table 4 Comparison of adverse events between gefitinib and erlotinib treatment in Japanese patients

\begin{tabular}{|c|c|c|c|c|c|c|c|c|}
\hline Study & Drug & $\begin{array}{l}\text { Number } \\
\text { of patients }\end{array}$ & $\begin{array}{l}\text { Treatment } \\
\text { line }\end{array}$ & $\begin{array}{l}\text { Rash } \\
\text { (Grade } \geq 3 \text { ) }\end{array}$ & $\begin{array}{l}\text { Diarrhea } \\
\text { (Grade } \geq 3 \text { ) }\end{array}$ & $\begin{array}{l}\text { Hepatotoxicity } \\
\text { (Grade } \geq 3 \text { ) }\end{array}$ & $\begin{array}{l}\text { ILD } \\
\text { (Grade 5) }\end{array}$ & Reference \\
\hline WJTOG3405 (Phase III) & Gefitinib & 86 & First line & $85.1 \%(2.3 \%)$ & $54.0 \%(1.1 \%)$ & $70.1 \%(27.6 \%)$ & $2.3 \%(1.16 \%)$ & 82 \\
\hline NEJ002 (Phase III) & Gefitinib & 114 & First line & $71.1 \%(5.3 \%)$ & $34.2 \%(0.9 \%)$ & $55.3 \%(26.3 \%)$ & $5.3 \%(0.88 \%)$ & 83 \\
\hline JO22903 (Phase II) & Erlotinib & 102 & First line & $83 \%(14 \%)$ & $81 \%(1 \%)$ & $33 \%(8 \%)$ & $4.85 \%(1.94 \%)$ & 27 \\
\hline
\end{tabular}

Abbreviation: ILD, interstitial lung disease.

tumor or metastases using a rebiopsy should be recommended for the further exploration of optimal treatment strategies after patients acquire resistance to EGFR-TKIs. ${ }^{75-77}$

\section{Difference between gefitinib and erlotinib}

The discovery that 4-anilinoquinazolines exhibit EGFR inhibitory activity led to the development of gefitinib and erlotinib, ${ }^{15}$ and both of these drugs can be used in Japan. Although erlotinib seems to have a slightly broader spectrum of kinase inhibition and to have a slightly stronger EGFR inhibitory activity in several EGFR mutations than gefitinib, ${ }^{78,79}$ both drugs are essentially EGFR-specific TKIs. The most prominent difference between these two drugs is the dose setting. The approved daily dose of erlotinib (150 mg) is equal to the maximum tolerated dose of erlotinib. In contrast, the daily dose of gefitinib has been set at $250 \mathrm{mg}$, which is approximately one-third of the maximum tolerated dose of gefitinib. ${ }^{80-83}$ This difference seems to have several influences, especially on central nervous system (CNS) lesion and adverse events.

In general, patients with CNS metastases suffer from a deterioration of their performance status and therefore do not have a long survival time. The primary treatment for CNS metastases in patients with NSCLC has traditionally consisted of whole-brain radiotherapy, surgery, or radiosurgery, while systemic chemotherapy has been thought to play a limited role because of the belief that the brain is a site of pharmacological sanctuary. ${ }^{84,85}$ However, several studies have documented the effectiveness of EGFR-TKIs ${ }^{86}$ for the treatment of CNS metastases of NSCLC. In addition, previous studies suggest that a higher cerebrospinal fluid concentration can be achieved with erlotinib than with gefitinib because of the dose setting; thus, erlotinib might be more effective for the treatment of CNS metastases, especially leptomeningeal metastases. ${ }^{87-89}$ The CNS is a common site of recurrence, possibly because of the poor penetration of chemotherapeutic agents into the CNS. ${ }^{90}$ Therefore, considering the higher cerebrospinal fluid concentration of erlotinib, patients may achieve a longer PFS with erlotinib treatment than with gefitinib treatment. Indeed, one pooled analysis has shown such results. ${ }^{91}$
Considering the dose setting, many adverse events, including rash and diarrhea, seem to occur more frequently in patients treated with erlotinib than with gefitinib (Table 4). However, hepatotoxicity seems to occur relatively frequently in patients treated with gefitinib (Table 4). Several reports have indicated that patients with hepatotoxicity after gefitinib can subsequently be treated with erlotinib without experiencing hepatotoxicity. ${ }^{92,93}$ This result might arise because of the difference in metabolic enzymes that are affected. ${ }^{93}$ In addition, interstitial lung disease is one of the most serious adverse events associated with EGFR-TKIs, and there seems to be no significant difference in the frequency of interstitial lung disease between the two drugs. ${ }^{37,94-96}$ Hepatotoxicity and interstitial lung disease, both of which are often associated with drug discontinuation, seem to occur independent of the dose setting. A recent Phase III trial directly comparing gefitinib and erlotinib demonstrated similar results. ${ }^{38}$

\section{Conclusion}

The outcome of cytotoxic chemotherapy for NSCLC had reached a plateau, but the discovery of EGFR mutations in 2004 opened a new era of personalized treatment for NSCLC. Subsequently, EML4-ALK, a novel driver oncogene, was found in 2007. ${ }^{97}$ Crizotinib, the first clinically available anaplastic lymphoma kinase TKI, appeared to be more effective (compared with standard chemotherapy) in NSCLC patients harboring EML4- $A L K{ }^{98}$ The introduction of these molecular targeted drugs into a clinical setting was followed by the identification of genetic changes that give rise to NSCLC and has been accompanied by appropriate patient selection.

Treatment with erlotinib therapy can dramatically delay disease progression and is well tolerated in patients harboring activating $E G F R$ mutations. Although erlotinib also has a mild efficacy for EGFR wild-type NSCLC, EGFR mutation is the strongest predictive biomarker for its efficacy, and mutations are more common in the Asian (including Japanese) population. In Japan, both gefitinib and erlotinib can be used as EGFR-TKIs. Furthermore, afatinib, an irreversible EGFR-TKI, can also be used, and this novel drug seems to 
have a significant effect on NSCLCs harboring an EGFR exon 19 deletion. ${ }^{99}$ Thus, clinicians should use each of these drugs in appropriate settings.

Acquired resistance, including EGFR secondary mutations (T790M and other rare mutations), MET gene amplification, PTEN gene downregulation, high-level hepatocyte growth factor expression, epithelial-mesenchymal transition, and conversion to small cell lung cancer, ${ }^{100-102}$ continues to restrict the durable long-term outcomes of erlotinib. Further efforts are needed to explore new strategies to improve the efficacy of erlotinib treatment in all settings and to overcome drug resistance.

\section{Disclosure}

The authors report no conflicts of interest in this work.

\section{References}

1. Siegel R, Naishadham D, Jemal A. Cancer statistics, 2013. CA Cancer J Clin. 2013;63(1):11-30.

2. Siegel R, DeSantis C, Virgo K, et al. Cancer treatment and survivorship statistics, 2012. CA Cancer J Clin. 2012;62(4):220-241.

3. Schiller JH, Harrington D, Belani CP, et al. Comparison of four chemotherapy regimens for advanced non-small-cell lung cancer. N Engl J Med. 2002;346(2):92-98.

4. Ohe Y, Ohashi Y, Kubota K, et al. Randomized Phase III study of cisplatin plus irinotecan versus carboplatin plus paclitaxel, cisplatin plus gemcitabine, and cisplatin plus vinorelbine for advanced nonsmall-cell lung cancer: Four-Arm Cooperative Study in Japan. Ann Oncol. 2007;18(2):317-323.

5. Pao W, Chmielecki J. Rational, biologically based treatment of EGFRmutant non-small-cell lung cancer. Nat Rev Cancer. 2010;10(11): 760-774.

6. Fukuoka M, Yano S, Giaccone G, et al. Multi-institutional randomized Phase II trial of gefitinib for previously treated patients with advanced non-small-cell lung cancer (The IDEAL 1 Trial) [corrected]. $J$ Clin Oncol. 2003;21(12):2237-2246.

7. Kris MG, Natale RB, Herbst RS, et al. Efficacy of gefitinib, an inhibitor of the epidermal growth factor receptor tyrosine kinase, in symptomatic patients with non-small cell lung cancer: a randomized trial. JAMA. 2003;290(16):2149-2158.

8. Thatcher N, Chang A, Parikh P, et al. Gefitinib plus best supportive care in previously treated patients with refractory advanced nonsmall-cell lung cancer: results from a randomised, placebo-controlled, multicentre study (Iressa Survival Evaluation in Lung Cancer). Lancet. 2005;366(9496):1527-1537.

9. Lynch TJ, Bell DW, Sordella R, et al. Activating mutations in the epidermal growth factor receptor underlying responsiveness of non-smallcell lung cancer to gefitinib. N Engl J Med. 2004;350(21):2129-2139.

10. Paez JG, Janne PA, Lee JC, et al. EGFR mutations in lung cancer: correlation with clinical response to gefitinib therapy. Science. 2004; 304(5676):1497-1500

11. Pao W, Miller V, Zakowski M, et al. EGF receptor gene mutations are common in lung cancers from "never smokers" and are associated with sensitivity of tumors to gefitinib and erlotinib. Proc Natl Acad Sci USA. 2004;101(36):13306-13311.

12. Fukuoka M, Wu YL, Thongprasert S, et al. Biomarker analyses and final overall survival results from a Phase III, randomized, open-label, first-line study of gefitinib versus carboplatin/paclitaxel in clinically selected patients with advanced non-small-cell lung cancer in Asia (IPASS). J Clin Oncol. 2011;29(21):2866-2874.
13. Mok TS, Wu YL, Thongprasert S, et al. Gefitinib or carboplatinpaclitaxel in pulmonary adenocarcinoma. $N$ Engl J Med. 2009;361(10): 947-957.

14. Shepherd FA, Rodrigues Pereira J, Ciuleanu T, et al. Erlotinib in previously treated non-small-cell lung cancer. $N$ Engl J Med. 2005;353(2): 123-132.

15. Barker AJ, Gibson KH, Grundy W, et al. Studies leading to the identification of ZD1839 (IRESSA): an orally active, selective epidermal growth factor receptor tyrosine kinase inhibitor targeted to the treatment of cancer. Bioorg Med Chem Lett. 2001;11(14):1911-1914.

16. Moyer JD, Barbacci EG, Iwata KK, et al. Induction of apoptosis and cell cycle arrest by CP-358,774, an inhibitor of epidermal growth factor receptor tyrosine kinase. Cancer Res. 1997;57(21):4838-4848.

17. Rosell R, Moran T, Queralt C, et al. Screening for epidermal growth factor receptor mutations in lung cancer. $N$ Engl J Med. 2009;361(10): 958-967.

18. Cortes-Funes H, Gomez C, Rosell R, et al. Epidermal growth factor receptor activating mutations in Spanish gefitinib-treated non-small-cell lung cancer patients. Ann Oncol. 2005;16(7):1081-1086.

19. Mitsudomi T, Kosaka T, Endoh H, et al. Mutations of the epidermal growth factor receptor gene predict prolonged survival after gefitinib treatment in patients with non-small-cell lung cancer with postoperative recurrence. J Clin Oncol. 2005;23(11):2513-2520.

20. Han SW, Kim TY, Jeon YK, et al. Optimization of patient selection for gefitinib in non-small cell lung cancer by combined analysis of epidermal growth factor receptor mutation, K-ras mutation, and Akt phosphorylation. Clin Cancer Res. 2006;12(8):2538-2544.

21. Mitsudomi T, Yatabe Y. Mutations of the epidermal growth factor receptor gene and related genes as determinants of epidermal growth factor receptor tyrosine kinase inhibitors sensitivity in lung cancer. Cancer Sci. 2007;98(12):1817-1824.

22. Roengvoraphoj M, Tsongalis GJ, Dragnev KH, Rigas JR. Epidermal growth factor receptor tyrosine kinase inhibitors as initial therapy for non-small cell lung cancer: focus on epidermal growth factor receptor mutation testing and mutation-positive patients. Cancer Treat Rev. 2013;39(8):839-850.

23. Jackman DM, Yeap BY, Sequist LV, et al. Exon 19 deletion mutations of epidermal growth factor receptor are associated with prolonged survival in non-small cell lung cancer patients treated with gefitinib or erlotinib. Clin Cancer Res. 2006;12(13):3908-3914.

24. Riely GJ, Pao W, Pham D, et al. Clinical course of patients with nonsmall cell lung cancer and epidermal growth factor receptor exon 19 and exon 21 mutations treated with gefitinib or erlotinib. Clin Cancer Res. 2006;12(3 Pt 1):839-844.

25. Lee VH, Tin VP, Choy TS, et al. Association of exon 19 and 21 EGFR mutation patterns with treatment outcome after first-line tyrosine kinase inhibitor in metastatic non-small-cell lung cancer. J Thorac Oncol. 2013;8(9):1148-1155

26. Yasuda H, Park E, Yun $\mathrm{CH}$, et al. Structural, biochemical, and clinical characterization of epidermal growth factor receptor (EGFR) exon 20 insertion mutations in lung cancer. Sci Transl Med. 2013; 5(216):216ra177.

27. Hall JG, Eis PS, Law SM, et al. Sensitive detection of DNA polymorphisms by the serial invasive signal amplification reaction. Proc Natl Acad Sci U S A. 2000;97(15):8272-8277.

28. Nagai Y, Miyazawa H, Huqun, et al. Genetic heterogeneity of the epidermal growth factor receptor in non-small cell lung cancer cell lines revealed by a rapid and sensitive detection system, the peptide nucleic acid-locked nucleic acid PCR clamp. Cancer Res. 2005;65(16): 7276-7282.

29. Yatabe Y, Hida T, Horio Y, Kosaka T, Takahashi T, Mitsudomi T A rapid, sensitive assay to detect EGFR mutation in small biopsy specimens from lung cancer. J Mol Diagn. 2006;8(3):335-341.

30. Kimura H, Kasahara K, Kawaishi M, et al. Detection of epidermal growth factor receptor mutations in serum as a predictor of the response to gefitinib in patients with non-small-cell lung cancer. Clin Cancer Res. 2006;12(13):3915-3921. 
31. Goto K, Satouchi M, Ishii G, et al. An evaluation study of EGFR mutation tests utilized for non-small-cell lung cancer in the diagnostic setting. Ann Oncol. 2012;23(11):2914-2919.

32. Zhou $\mathrm{C}, \mathrm{Wu} \mathrm{YL}$, Chen $\mathrm{G}$, et al. Erlotinib versus chemotherapy as first-line treatment for patients with advanced EGFR mutationpositive non-small-cell lung cancer (OPTIMAL, CTONG-0802): a multicentre, open-label, randomised, Phase III study. Lancet Oncol. 2011;12(8):735-742.

33. Rosell R, Carcereny E, Gervais R, et al. Erlotinib versus standard chemotherapy as first-line treatment for European patients with advanced EGFR mutation-positive non-small-cell lung cancer (EURTAC): a multicentre, open-label, randomised Phase III trial. Lancet Oncol. 2012;13(3):239-246.

34. Wu YL, Liam CK, Zhou C, et al. First-line erlotinib versus cisplatin/ gemcitabine (GP) in patients with advanced EGFR mutation-positive non-small-cell lung cancer (NSCLC): interim analyses from the Phase III, open-label, ENSURE study. J Thorac Oncol. 2013;8(Suppl 2):S603.

35. Chen G, Feng J, Zhou C, et al. Quality of life (QoL) analyses from OPTIMAL (CTONG-0802), a Phase III, randomised, open-label study of first-line erlotinib versus chemotherapy in patients with advanced EGFR mutation-positive non-small-cell lung cancer (NSCLC). Ann Oncol. 2013;24(6):1615-1622.

36. Yamada K, Takayama K, Kawakami S, et al. Phase II trial of erlotinib for Japanese patients with previously treated non-small-cell lung cancer harboring EGFR mutations: results of Lung Oncology Group in Kyushu (LOGiK0803). Jpn J Clin Oncol. 2013;43(6):629-635.

37. Goto K, Nishio M, Yamamoto N, et al. A prospective, Phase II, open-label study (JO22903) of first-line erlotinib in Japanese patients with epidermal growth factor receptor (EGFR) mutation-positive advanced non-smallcell lung cancer (NSCLC). Lung Cancer. 2013;82(1):109-114.

38. Katakami N, Morita S, Yoshioka H, et al. Randomized Phase III study comparing gefitinib (G) with erlotinib (E) in patients (pts) with previously treated advanced lung adenocarcinoma (LA): WJOG 5108L [abstract]. J Clin Oncol. 2014;32(Suppl 5):8041.

39. Zhu CQ, da Cunha Santos G, Ding K, et al. Role of KRAS and EGFR as biomarkers of response to erlotinib in National Cancer Institute of Canada Clinical Trials Group Study BR.21. J Clin Oncol. 2008;26(26): 4268-4275.

40. Yoshioka H, Hotta K, Kiura K, et al. A Phase II trial of erlotinib monotherapy in pretreated patients with advanced non-small cell lung cancer who do not possess active EGFR mutations: Okayama Lung Cancer Study Group trial 0705. J Thorac Oncol. 2010;5(1):99-104.

41. Matsuura S, Inui N, Ozawa Y, et al. Phase II study of erlotinib as thirdline monotherapy in patients with advanced non-small-cell lung cancer without epidermal growth factor receptor mutations. Jpn J Clin Oncol. 2011;41(8):959-963.

42. Karampeazis A, Voutsina A, Souglakos J, et al. Pemetrexed versus erlotinib in pretreated patients with advanced non-small cell lung cancer: a Hellenic Oncology Research Group (HORG) randomized Phase III study. Cancer. 2013;119(15):2754-2764.

43. Jazieh AR, Al Sudairy R, Abu-Shraie N, Al Suwairi W, Ferwana M, Murad MH. Erlotinib in wild type epidermal growth factor receptor non-small cell lung cancer: a systematic review. Ann Thorac Med. 2013;8(4):204-208.

44. Garassino MC, Martelli O, Broggini M, et al. Erlotinib versus docetaxel as second-line treatment of patients with advanced non-small-cell lung cancer and wild-type EGFR tumours (TAILOR): a randomised controlled trial. Lancet Oncol. 2013;14(10):981-988.

45. Kawaguchi T, Ando M, Asami K, et al. Randomized Phase III trial of erlotinib versus docetaxel as second- or third-line therapy in patients with advanced non-small-cell lung cancer: Docetaxel and Erlotinib Lung Cancer Trial (DELTA). J Clin Oncol. 2014;32(18):1902-1908.

46. Ishii Y, Maemondo M, Okudera K, et al. A Phase II study of erlotinib monotherpay in patients with previously treated advanced non-small cell lung cancer (NSCLC) without EGFR gene mutation who have never/ light smoking history: NEJ006/TCOG0903 [abstract]. J Clin Oncol. 2012;30 Suppl:7561.
47. Yonesaka K, Zejnullahu K, Lindeman N, et al. Autocrine production of amphiregulin predicts sensitivity to both gefitinib and cetuximab in EGFR wild-type cancers. Clin Cancer Res. 2008;14(21): 6963-6973.

48. Chang MH, Ahn HK, Lee J, et al. Clinical impact of amphiregulin expression in patients with epidermal growth factor receptor (EGFR) wild-type nonsmall cell lung cancer treated with EGFR-tyrosine kinase inhibitors. Cancer. 2011;117(1):143-151.

49. Addison CL, Ding K, Zhao H, et al. Plasma transforming growth factor alpha and amphiregulin protein levels in NCIC Clinical Trials Group BR.21. J Clin Oncol. 2010;28(36):5247-5256.

50. Inoue A, Kobayashi K, Usui K, et al. First-line gefitinib for patients with advanced non-small-cell lung cancer harboring epidermal growth factor receptor mutations without indication for chemotherapy. $J$ Clin Oncol. 2009;27(9):1394-1400.

51. Lee SM, Khan I, Upadhyay S, et al. First-line erlotinib in patients with advanced non-small-cell lung cancer unsuitable for chemotherapy (TOPICAL): a double-blind, placebo-controlled, Phase III trial. Lancet Oncol. 2012;13(11):1161-1170.

52. Gridelli C, Maione P, Rossi A, et al. Potential treatment options after first-line chemotherapy for advanced NSCLC: maintenance treatment or early second-line? Oncologist. 2009;14(2):137-147.

53. Sandler A, Gray R, Perry MC, et al. Paclitaxel-carboplatin alone or with bevacizumab for non-small-cell lung cancer. $N$ Engl $J$ Med. 2006;355(24):2542-2550.

54. Ciuleanu T, Brodowicz T, Zielinski C, et al. Maintenance pemetrexed plus best supportive care versus placebo plus best supportive care for non-small-cell lung cancer: a randomised, double-blind, Phase III study. Lancet. 2009;374(9699):1432-1440.

55. Paz-Ares L, de Marinis F, Dediu M, et al. Maintenance therapy with pemetrexed plus best supportive care versus placebo plus best supportive care after induction therapy with pemetrexed plus cisplatin for advanced non-squamous non-small-cell lung cancer (PARAMOUNT): a double-blind, Phase III, randomised controlled trial. Lancet Oncol. 2012;13(3):247-255.

56. Paz-Ares LG, de Marinis F, Dediu M, et al. PARAMOUNT: final overall survival results of the Phase III study of maintenance pemetrexed versus placebo immediately after induction treatment with pemetrexed plus cisplatin for advanced nonsquamous non-small-cell lung cancer. $J$ Clin Oncol. 2013;31(23):2895-2902.

57. Cappuzzo F, Ciuleanu T, Stelmakh L, et al. Erlotinib as maintenance treatment in advanced non-small-cell lung cancer: a multicentre, randomised, placebo-controlled Phase III study. Lancet Oncol. 2010;11(6):521-529.

58. Jackman D, Pao W, Riely GJ, et al. Clinical definition of acquired resistance to epidermal growth factor receptor tyrosine kinase inhibitors in non-small-cell lung cancer. J Clin Oncol. 2010;28(2): 357-360.

59. Herbst RS, Prager D, Hermann R, et al. TRIBUTE: a Phase III trial of erlotinib hydrochloride (OSI-774) combined with carboplatin and paclitaxel chemotherapy in advanced non-small-cell lung cancer. J Clin Oncol. 2005;23(25):5892-5899.

60. Gatzemeier U, Pluzanska A, Szczesna A, et al. Phase III study of erlotinib in combination with cisplatin and gemcitabine in advanced non-small-cell lung cancer: the Tarceva Lung Cancer Investigation Trial. J Clin Oncol. 2007;25(12):1545-1552.

61. Mok TS, Wu YL, Yu CJ, et al. Randomized, placebo-controlled, Phase II study of sequential erlotinib and chemotherapy as first-line treatment for advanced non-small-cell lung cancer. J Clin Oncol. 2009;27(30): 5080-5087.

62. Li T, Ling YH, Goldman ID, Perez-Soler R. Schedule-dependent cytotoxic synergism of pemetrexed and erlotinib in human non-small cell lung cancer cells. Clin Cancer Res. 2007;13(11):3413-3422.

63. Wu YL, Lee JS, Thongprasert S, et al. Intercalated combination of chemotherapy and erlotinib for patients with advanced stage non-smallcell lung cancer (FASTACT-2): a randomised, double-blind trial. Lancet Oncol. 2013;14(8):777-786. 
64. Kanda S, Ohe Y, Horinouchi H, et al. Phase II study of gefitinib and inserted cisplatin plus docetaxel as a first-line treatment for advanced non-small cell lung cancer haboring an epidermal growth factor receptor activating mutation [abstract]. J Clin Oncol. 2013;31 Suppl:8064.

65. Herbst RS, Ansari R, Bustin F, et al. Efficacy of bevacizumab plus erlotinib versus erlotinib alone in advanced non-small-cell lung cancer after failure of standard first-line chemotherapy (BeTa): a double-blind, placebocontrolled, Phase III trial. Lancet. 2011;377(9780):1846-1854.

66. Kato T, Seto T, Nishio M, et al. Erlotinib plus bevacizumab (EB) versus erlotinib alone $(\mathrm{E})$ as first-line treatment for advanced EGFR mutation-positive nonsquamous non-small cell lung cancer (NSCLC): an open-label randomized trial [abstract]. J Clin Oncol. 2014; 32(Suppl 5):8005.

67. Chaft JE, Oxnard GR, Sima CS, Kris MG, Miller VA, Riely GJ. Disease flare after tyrosine kinase inhibitor discontinuation in patients with EGFR-mutant lung cancer and acquired resistance to erlotinib or gefitinib: implications for clinical trial design. Clin Cancer Res. 2011;17(19):6298-6303.

68. Kuo CH, Lin SM, Lee KY, et al. Subsequent chemotherapy improves survival outcome in advanced non-small-cell lung cancer with acquired tyrosine kinase inhibitor resistance. Clin Lung Cancer. 2010;11(1): 51-56.

69. Solca F, Dahl G, Zoephel A, et al. Target binding properties and cellular activity of afatinib (BIBW 2992), an irreversible ErbB family blocker J Pharmacol Exp Ther. 2012;343(2):342-350.

70. Schiller JH, Akerley WL, Brugger W, et al. Results from ARQ 197-209: a global randomized placebo-controlled Phase II clinical trial of erlotinib plus ARQ 197 versus erlotinib plus placebo in previously treated EGFR inhibitor-naive patients with locally advanced or metastatic non-small cell lung cancer (NSCLC) [abstract]. J Clin Oncol. 2010; 28(Supp1 18):LBA7502.

71. Spigel DR, Ervin TJ, Ramlau R, et al. Final efficacy results from OAM4558g, a randomized Phase II study evaluating MetMAb or placebo in combination with erlotinib in advanced NSCLC [abstract]. J Clin Oncol. 2011;29 Suppl:7505.

72. Nishie K, Kawaguchi T, Tamiya A, et al. Epidermal growth factor receptor tyrosine kinase inhibitors beyond progressive disease: a retrospective analysis for Japanese patients with activating EGFR mutations. J Thorac Oncol. 2012;7(11):1722-1727.

73. Yu HA, Sima CS, Huang J, et al. Local therapy with continued EGFR tyrosine kinase inhibitor therapy as a treatment strategy in EGFR-mutant advanced lung cancers that have developed acquired resistance to EGFR tyrosine kinase inhibitors. J Thorac Oncol. 2013;8(3):346-351.

74. Janne PA, Wang X, Socinski MA, et al. Randomized Phase II trial of erlotinib alone or with carboplatin and paclitaxel in patients who were never or light former smokers with advanced lung adenocarcinoma: CALGB 30406 trial. J Clin Oncol. 2012;30(17):2063-2069.

75. Arcila ME, Oxnard GR, Nafa K, et al. Rebiopsy of lung cancer patients with acquired resistance to EGFR inhibitors and enhanced detection of the T790M mutation using a locked nucleic acid-based assay. Clin Cancer Res. 2011;17(5):1169-1180.

76. Yu HA, Arcila ME, Rekhtman N, et al. Analysis of tumor specimens at the time of acquired resistance to EGFR-TKI therapy in 155 patients with EGFR-mutant lung cancers. Clin Cancer Res. 2013;19(8): 2240-2247.

77. Hata A, Katakami N, Yoshioka H, et al. Rebiopsy of non-small cell lung cancer patients with acquired resistance to epidermal growth factor receptor-tyrosine kinase inhibitor: comparison between T790M mutation-positive and mutation-negative populations. Cancer. 2013;119(24): 4325-4332.

78. Fabian MA, Biggs WH 3rd, Treiber DK, et al. A small moleculekinase interaction map for clinical kinase inhibitors. Nat Biotechnol. 2005;23(3):329-336

79. Kancha RK, von Bubnoff N, Peschel C, Duyster J. Functional analysis of epidermal growth factor receptor (EGFR) mutations and potential implications for EGFR targeted therapy. Clin Cancer Res. 2009;15(2): 460-467.
80. Cohen MH, Williams GA, Sridhara R, Chen G, Pazdur R. FDA drug approval summary: gefitinib (ZD1839) (Iressa) tablets. Oncologist. 2003;8(4):303-306.

81. Cohen MH, Johnson JR, Chen YF, Sridhara R, Pazdur R. FDA drug approval summary: erlotinib (Tarceva) tablets. Oncologist. 2005;10(7): $461-466$.

82. Nakagawa K, Tamura T, Negoro S, et al. Phase I pharmacokinetic trial of the selective oral epidermal growth factor receptor tyrosine kinase inhibitor gefitinib ("Iressa", ZD1839) in Japanese patients with solid malignant tumors. Ann Oncol. 2003;14(6):922-930.

83. Yamamoto N, Horiike A, Fujisaka Y, et al. Phase I dose-finding and pharmacokinetic study of the oral epidermal growth factor receptor tyrosine kinase inhibitor Ro50-8231 (erlotinib) in Japanese patients with solid tumors. Cancer Chemother Pharmacol. 2008;61(3): 489-496.

84. Khuntia D, Brown P, Li J, Mehta MP. Whole-brain radiotherapy in the management of brain metastasis. J Clin Oncol. 2006;24(8): 1295-1304.

85. Langer CJ, Mehta MP. Current management of brain metastases, with a focus on systemic options. J Clin Oncol. 2005;23(25): 6207-6219.

86. Park SJ, Kim HT, Lee DH, et al. Efficacy of epidermal growth factor receptor tyrosine kinase inhibitors for brain metastasis in non-small cell lung cancer patients harboring either exon 19 or 21 mutation. Lung Cancer. 2012;77(3):556-560.

87. Togashi Y, Masago K, Fukudo M, et al. Cerebrospinal fluid concentration of erlotinib and its active metabolite OSI-420 in patients with central nervous system metastases of non-small cell lung cancer. J Thorac Oncol. 2010;5(7):950-955.

88. Togashi Y, Masago K, Masuda S, et al. Cerebrospinal fluid concentration of gefitinib and erlotinib in patients with non-small cell lung cancer. Cancer Chemother Pharmacol. 2012;70(3):399-405.

89. Lee E, Keam B, Kim DW, et al. Erlotinib versus gefitinib for control of leptomeningeal carcinomatosis in non-small-cell lung cancer. J Thorac Oncol. 2013;8(8):1069-1074.

90. Omuro AM, Kris MG, Miller VA, et al. High incidence of disease recurrence in the brain and leptomeninges in patients with nonsmall cell lung carcinoma after response to gefitinib. Cancer. 2005;103(11): 2344-2348.

91. Paz-Ares L, Soulieres D, Melezinek I, et al. Clinical outcomes in nonsmall-cell lung cancer patients with EGFR mutations: pooled analysis. J Cell Mol Med. 2010;14(1-2):51-69.

92. Takeda M, Okamoto I, Fukuoka M, Nakagawa K. Successful treatment with erlotinib after gefitinib-related severe hepatotoxicity. J Clin Oncol. 2010;28(17):e273-e274

93. Kijima T, Shimizu T, Nonen S, et al. Safe and successful treatment with erlotinib after gefitinib-induced hepatotoxicity: difference in metabolism as a possible mechanism. J Clin Oncol. 2011;29(19): e588-e590.

94. Mitsudomi T, Morita S, Yatabe Y, et al. Gefitinib versus cisplatin plus docetaxel in patients with non-small-cell lung cancer harbouring mutations of the epidermal growth factor receptor (WJTOG3405): an open label, randomised Phase III trial. Lancet Oncol. 2010;11(2): 121-128.

95. Maemondo M, Inoue A, Kobayashi K, et al. Gefitinib or chemotherapy for non-small-cell lung cancer with mutated EGFR. $N$ Engl J Med. 2010;362(25):2380-2388.

96. Togashi Y, Masago K, Fujita S, et al. Differences in adverse events between $250 \mathrm{mg}$ daily gefitinib and $150 \mathrm{mg}$ daily erlotinib in Japanese patients with non-small cell lung cancer. Lung Cancer. 2011;74(1): 98-102.

97. Soda M, Choi YL, Enomoto M, et al. Identification of the transforming EML4-ALK fusion gene in non-small-cell lung cancer. Nature. 2007;448(7153):561-566.

98. Shaw AT, Kim DW, Nakagawa K, et al. Crizotinib versus chemotherapy in advanced ALK-positive lung cancer. $N$ Engl J Med. 2013;368(25) 2385-2394. 
99. Yang JC, Sequist LV, Schuler MH, et al. Overall survival (OS) in patients (pts) with advanced non-small cell lung cancer (NSCLC) harboring common (Del19/L858R) epidermal growth factor receptor mutations (EGFR mut): pooled analysis of two large open-label Phase III studies (LUX-Lung 3 [LL3] and LUX-Lung 6 [LL6]) comparing afatinib with chemotherapy (CT) [abstract]. J Clin Oncol. 2014;32(Suppl 5):8004.

100. Kobayashi S, Boggon TJ, Dayaram T, et al. EGFR mutation and resistance of non-small-cell lung cancer to gefitinib. $N$ Engl $J$ Med. 2005;352(8):786-792.
101. Suda K, Mizuuchi H, Maehara Y, Mitsudomi T. Acquired resistance mechanisms to tyrosine kinase inhibitors in lung cancer with activating epidermal growth factor receptor mutation - diversity, ductility, and destiny. Cancer Metastasis Rev. 2012;31(3-4):807-814.

102. Remon J, Moran T, Majem M, et al. Acquired resistance to epidermal growth factor receptor tyrosine kinase inhibitors in EGFR-mutant non-small cell lung cancer: a new era begins. Cancer Treat Rev. 2014;40(1):93-101.

\section{Publish your work in this journal}

Drug Design, Development and Therapy is an international, peerreviewed open-access journal that spans the spectrum of drug design and development through to clinical applications. Clinical outcomes, patient safety, and programs for the development and effective, safe, and sustained use of medicines are a feature of the journal, which has also been accepted for indexing on PubMed Central. The manuscript management system is completely online and includes a very quick and fair peer-review system, which is all easy to use. Visit http://www.dovepress.com/testimonials.php to read real quotes from published authors.

Submit your manuscript here: http://www.dovepress.com/drug-design-development-and-therapy-journal 